\title{
Potenciais evocados auditivos do tronco encefálico por condução óssea em indivíduos normais*****
}

\author{
Bone conduction auditory brainstem responses in normal hearing \\ individuals
}

\author{
Vanessa Sabino de Freitas* \\ Kátia de Freitas Alvarenga** \\ Marina Morettin*** \\ Elidiane Fugiwara de Souza*** \\ Orozimbo Alves Costa Filho****
}

\begin{abstract}
* Fonoaudióloga. Mestranda em Fonoaudiologia pela Faculdade de Odontologia de Bauru - Universidade de São Paulo. Endereço para correspondência: Rua Joaquim Fidélis, 7-65 - Apto. 53 - Bauru - SP - CEP 17012-180 (vanfreitas@gmail.com).

**Fonoaudióloga. Professora Associada do Departamento de Fonoaudiologia da Faculdade de Odontologia de Bauru - Universidade de São Paulo.
\end{abstract}

***Fonoaudióloga. Especialista em Audiologia Clínica e Educacional pelo Centro de Pesquisas Audiológicas do Hospital de Reabilitação de Anomalias Craniofaciais - Universidade de São Paulo.

****Médico Otologista. Professor Titular do Departamento de Fonoaudiologia pela Faculdade de Odontologia de Bauru - Universidade de São Paulo. Coordenador do Centro de Pesquisas Audiológicas, do Hospital de Reabilitação de Anomalias Craniofaciais da Universidade de São Paulo.

*****Trabalho Realizado na Faculdade de Odontologia de Bauru -

Universidade de São Paulo. Apoio Fundação de Amparo à Pesquisa do Estado de São Paulo.

Artigo de Pesquisa

Artigo Submetido a Avaliação por Pares

Conflito de Interesse: não

Recebido em 17.06.2005.

Revisado em 31.08.2005; 16.03.2006; 30.08.2006.

Aceito para Publicação em 26.10.2006.

\begin{abstract}
Background: bone conduction auditory brainstem responses (ABR) in normal hearing individuals. Aim: to evaluate the clinical applicability of bone conduction ABR, characterizing normality and determining an assessment protocol. Method: participants of this study were 22 individuals with normal hearing (20dB NA), with ages between 20 and 30 years, 14 female and 8 male. All individuals were assessed using air and bone (vibrator positioned on the forehead and mastoid) conduction ABR. EP25 equipment, Interacoustic; 3A insertion phone; B-71 bone vibrator; click stimulus. Results: it was possible to evaluate the bone conduction ABR in all individuals. The results demonstrate that the electrophysiological threshold obtained when the vibrator was positioned on the forehead $(32.69 \pm 5.63$ and $32.5 \pm 7.07 \mathrm{~dB}$ nHL) was higher than that obtained when the vibrator was positioned on the mastoid (25.00 \pm 7.33 and $30.00 \pm 5.34 \mathrm{~dB} \mathrm{nHL}$ ) for both genders respectively. For this reason the vibrator was positioned on the mastoid. The electrophysiological threshold obtained by bone conduction was higher than that obtained by air conduction for both genders and also when all individuals were grouped together. Thus it is necessary to use a correction factor, according to the results, of $10 \mathrm{~dB}$ nHL. The latency-intensity values of the $\mathrm{V}$ wave in the ipsilateral and contralateral recordings differed statistically according to gender, and should be considered separately. The value of $26.81 \pm 6.99 \mathrm{~dB} \mathrm{nHL}$ was adopted as being the normal threshold for bone conduction ABR. Conclusion: it is possible to evaluate bone conduction ABR in the clinical environment. These results, when considered along with the air conduction ABR, increase the chances of a more precise diagnosis regarding the type of hearing loss.
\end{abstract}

Key Words: Evoked potentials; Auditory; Brain Stem; Bone Conduction.

\section{Resumo}

Tema: potenciais evocados auditivos do tronco encefálico (PEATEs) por condução óssea. Objetivo: avaliar a aplicabilidade clínica da pesquisa dos PEATEs por condução óssea, caracterizando a normalidade e determinando um protocolo de avaliação. Método: participaram deste estudo 22 indivíduos, na faixa etária entre 20 e 30 anos, sendo 14 do sexo feminino e 8 do sexo masculino, com audição normal (20dB NA). Os indivíduos foram avaliados por meio dos PEATEs por condução aérea e óssea (vibrador na fronte e mastóide). Equipamento EP25, Interacoustic; fone de inserção 3A; vibrador ósseo B-71; estímulo click. Resultados: foi possível realizar a pesquisa dos PEATEs por condução óssea em todos os indivíduos avaliados. Os resultados demonstraram que o limiar eletrofisiológico obtido com o vibrador na fronte $(32,69 \pm 5,63$ e $32,5 \pm 7,07 \mathrm{~dB} \mathrm{nHL})$ foi maior do que quando o vibrador foi posicionado na mastóide $(25,00 \pm 7,33$ e 30,00 $\pm 5,34 \mathrm{~dB} \mathrm{nHL})$, tanto para o sexo feminino quanto para o sexo masculino, respectivamente. Assim, optou-se pelo posicionamento do vibrador na mastóide. O limiar eletrofisiológico obtido por condução óssea foi maior que o limiar por condução áerea, com diferença estatisticamente significante, nos sexos feminino e masculino, e com todos os indivíduos agrupados. Assim, faz-se necessária a utilização do fator de correção, que de acordo com os resultados deve ser de aproximadamente $10 \mathrm{~dB}$ nHL. Os valores de normalidade para a função latência-intensidade da onda V no registro ipsilataral e contralateral diferem estatisticamente de acordo com o sexo feminino e masculino, devendo ser considerados separadamente. Para a normalidade do limiar eletrofisiológico por condução óssea adotou-se o valor de 26,81 \pm 6,99 dB nHL. Conclusão: é possível realizar os PEATEs por condução óssea na prática clínica e em conjunto com os potenciais por condução aérea aumenta as possibilidades de um diagnóstico mais preciso quanto ao tipo de perda auditiva.

Palavras-Chave: Potenciais Evocados Auditivos do Tronco Encefálico; Potenciais Evocados Auditivos; Condução Óssea.

Referenciar este material como:

FREITAS, V. S. de.; ALVARENGA, K. F.; MORETTIN, M.; SOUZA, E. F.; COSTA FILHO, O. A. Bone conduction auditory brainstem responses in normal hearing $\Omega$ individuals (original title: Potenciais evocados auditivos do tronco encefálico por condução óssea em indivíduos normais). Pró-Fono Revista de Atualização $\sum 3$ Científica, Barueri (SP), v. 18, n. 3, p.323-330, set.-dez. 2006. 


\section{Introduction}

In paediatric audiology practice, hearing loss may be defined through behavioral tests (visual reinforcement audiometry, pure tone audiometry with headphone or free field), acoustic measurement (evoked otoacoustic emissions and acoustic reflex threshold) and auditory evoked response measurement, auditory brainstem response - ABR, and recently, the steady state auditory response (SSR) [Roberson et al, 2003; Stueve e O'Rourke, 2003; Luts et al, 2004; Swanepoel et al, 2004; Santiago-Rodriguez et al, 2005]).

Nevertheless, defining the type of hearing loss (conductive, mixed or sensory neural), in most instances, is not an easy task, since behavioral tests demand that the child has a cognitive knowledge to understand the complex orders, many times, not expected for his/her age.

The research of evoked otoacoustic emissions was a great advance for the diagnosis of sensory neural hearing loss, for it is an objective test which assesses the functionality of outer hair cells on the cochlea, therefore, an important tool for clinical and newborn hearing screening (Fuzetti and Lewis, 2003). Nevertheless, the accomplishment of these procedures in children who were with otitis and external and/or middle ear malformation is hindered, for the prerequisite for the test to be performed is the integrity of the external and middle ear (Doyle et al., 2004; Oostenbrink and VerhaagenWarnaar, 2004; Hof et al, 2005; Jansen et al, 2005). Silveira et al. (2003) described that hearing loss is one of the most common clinical findings in patients presented with ear malformation, thus, it is crucial to identify and classify the hearing loss, so as to begin the treatment as early as possible.

In these cases, the possibility of obtaining the electrophysiological threshold by bone conduction brainstem auditory evoked potentials seems to be the procedure indicated to provide data on the auditory function, in sensorial and neural aspects. Some studies were carried out using ABR by bone conduction stimulation, in animals (Sohmer and Freman, 2001), in children (Cornacchia et al, 1983; Stuart and Yang, 2001; Fichino, 2005; Chapchap, 2002; Sheykholeslami et al, 2003); adults presented with conductive hearing loss (Maudin and Jeger, 1979), and normal adults (Maudin and Jeger, 1979; Cornacchia et al, 1983; Gorga et al, 1993; Freitas et al, 2004).

Among these studies, a few focused on the electrophysiological threshold and analysis of the latency-intensity function of $\mathrm{V}$ wave by bone conduction. Cornacchia et al. (1983) e Stuart and Yang (2001) found similar electrophysiological thresholds obtained by air and bone conduction, being that the conductive hearing loss did not alter the electrophysiological threshold obtained by bone conduction (Maudin and Jerger, 1979).

Another important aspect considered in the accomplishment of ABR, by bone conduction, is the region, in the skull, on which the bone vibrator will be positioned. The positioning of the vibrator in the temporal bone region, near the stimulated ear, was advocated by Shiraishi et al. (1985) apud Kaga and Tanaka (1995) who reported that the bone conduction thresholds, with the vibrator positioned on the forehead, had a $10 \mathrm{~dB}$ attenuation as compared to thresholds with the vibrator positioned on the mastoid bone. Shomer et al. (2000) while studying the involvement of spinal brain liquid in the transmission of vibratory energy by means of research of audiometric threshold by bone conduction, observed that it was smaller when the vibrator was positioned on the temporal bone, as compared to the frontal bone. Yang et al. (1987) described that when the vibrator is placed in the mastoid region, in newborns and 1-year old children, the latency of $\mathrm{V}$ wave is smaller, as compared to frontal and occipital bones, being these differences small, when adults are evaluated.

In the literature consulted, the research of ABR by bone conduction, is presented as a little utilized procedure, owing to some interfering factors such as the presence of artifacts, the click frequency range (1 to $4000 \mathrm{~Hz})$ and the need of masking (Campbell et al. 2004). However, there is a consensus that its utilization to evaluate infants and children is extremely useful, providing data on the electrophysiological evaluation of the auditory system (Maudin and Jerger, 1979; Campbell, 2004).

Flabiano et al (2002) carried out a study to verify the compatibility of the results obtained, from two different equipments, in the accomplishment of $\mathrm{ABR}$, and observed a statistically significant difference as for the values of absolute latencies for waves I, III, V, interpeaks I-III and I-V, amplitude of waves I, III, V, and the amplitude relation V/I obtained with the two equipments studied. Thus, they concluded that the ABR equipment utilized must be considered in the data analysis, ensuring reliable results and increasing the diagnostic precision. 
The present study aimed to evaluate the clinical applicability of auditory brainstem responses by bone conduction, characterizing the normality and determining an evaluation protocol.

\section{Method}

The present study was carried out at the Speech Pathology and Audiology Clinic, São Paulo University, Bauru campus. All volunteers received an information letter and signed a compliance regarding the participation in the study and divulging of their results, according to Resolution 196/96, approved by the Research Ethics Committee with the Craniofacial Anomalies Rehabilitation Hospital (HRAC-USP) - Research Protocol \# 167/2001, on November 14, 2001.

Twenty-two subjects, being 14 females and 8 males in the age range 20-30 years, with normal hearing (20dBNA) verified at the conventional audiological evaluation ( pure tone audiometry, speech audiometry and acoustic admittance measurement), participated in this study. The adult population was selected so as to guarantee the accuracy of the results on auditory behavioral and electrophysiological evaluations, all important for comparative data analysis.

The parameters utilized for ABR research by air and bone conduction are presented in Box 1 .

The electrophysiological thresholds by air and bone conduction, with monoaural stimulation were researched, and the ear to be tested was randomly defined, i.e., sometimes the right ear and sometimes the left one, for each subject assessed. Masking was not utilized, since the subjects were normal hearing.

EP25, Interacoustic evoked potentials system was used for the recording of ABR.

\section{Procedure}

The electrophysiological threshold obtained by air conduction was researched by diminishing the intensity every $20 \mathrm{~dB} \mathrm{nHL}$ till the $\mathrm{V}$ wave was no longer visualized, increasing it every $5 \mathrm{~dB} \mathrm{nHL}$ so as to determine the last intensity in which the $\mathrm{V}$ wave was registered. On the other hand, by bone conduction, the intensity was diminished every $10 \mathrm{~dB} \mathrm{nHL}$, following, then, the same procedure to determine the air electrophysiological threshold, however, with the analysis of latency-intensity function for the $\mathrm{V}$ wave. In both cases, the research was carried out twice, in each intensity, in order to verify the reproducibility of waves.

Aiming at determining the best positioning for the vibrator, so as to diminish the electrical artifact, the recording was performed with the vibrator positioned on the forehead and then on the mastoid.

Analysis of the results

The results underwent a descriptive statistical treatment (mean, minimum and maximum, SD), Student's $t$ test for comparison between genders and paired $t$ test for comparisons among groups.

BOX 1. Parameters utilized for the research of air and bone conduction auditory brainstem responses.

\begin{tabular}{|c|c|c|}
\hline Parameters & Air conduction & Bone conduction \\
\hline Transducer & 3A insertion phone & B-70 Vibrator \\
\hline Stimulus & Click & Click \\
\hline Rate & 21.1 clicks $/ \mathrm{s}$ & 27.7 clicks $/ \mathrm{s}$ \\
\hline Filter & 30 a $3000 \mathrm{~Hz}$ & 30 a $3000 \mathrm{~Hz}$ \\
\hline $\begin{array}{l}\text { Stimulus intensity for the beginning of } \\
\text { research of the electrophysiological } \\
\text { threshold }\end{array}$ & $80 \mathrm{dBnHL}$ & $60 \mathrm{dBnHL}$ \\
\hline Positioning of electrodes & $\begin{array}{l}\text { Active electrode in Fz; reference electrodes } \\
\text { in A1 and A2 (ispilateral and contralateral } \\
\text { records) }\end{array}$ & $\begin{array}{c}\text { Active electrode in Fz; reference electrodes } \\
\text { in A1 and A2 (ispilateral and contralateral } \\
\text { records) }\end{array}$ \\
\hline Vibrator pressure & $\ldots$ & Between 400 e 450 grams \\
\hline
\end{tabular}




\section{Results}

It was not possible to accomplish the research of $\mathrm{ABR}$, by bone conduction, in intensities 60 and $55 \mathrm{~dB} \mathrm{nHL}$ in all subjects researched, owing to the high rejection level, thus, the research was begun in $50 \mathrm{~dB}$ nHL.

Table 1 shows the electrophysiological thresholds values ( $\mathrm{dB} \mathrm{nHL}$ ) obtained by air conduction, bone conduction (vibrator positioned on the mastoid and forehead), V wave's absolute latencies obtained by bone conduction with the vibrator positioned on the mastoid, in intensities of 50, 40, 30 and 20dB nHL (ipsi and contralateral records).

Table 2 shows the descriptive statistical analysis and the result of Student's $t$ test comparing the electrophysiological thresholds obtained with the bone vibrator positioned on the forehead and mastoid, in all subjects evaluated. No statistically significant difference was observed between genders while comparing the positioning of the vibrator.

Figures 1 and 2 present the research of electrophysiological thresholds, ipsilateral recording, obtained in a female subject (subject 18 in Table I), with the vibrator positioned on the forehead and mastoid, respectively.

According to the results, positioning the vibrator on the mastoid was chosen, being this the position considered in all analyses thereafter.

Table 3 shows the descriptive statistical analysis and the result of the paired $t$ test accomplished to compare the electrophysiological thresholds ( $\mathrm{dB} \mathrm{nHL}$ ) obtained by air and bone conduction, for females, males and with all subjects grouped.

The results showed a statistically significant difference, when compared the electrophysiological thresholds obtained by air and bone conduction for female and male genders, and with all subjects grouped.

As for the time of recording for the research of electrophysiological thresholds, the mean was 30 minutes for the stimulation both by air conduction and bone conduction, nevertheless, for some subjects, this time was greater in the assessment by bone conduction, owing to the electrical artifact observed, being necessary the evaluation more than twice, in each intensity, for a better definition of $\mathrm{V}$ wave. This occurred mainly in the weaker intensities, in which the amplitude of ABRs is smaller.

In weaker intensities, to define the presence of V wave, the SN10 negative contingent was utilized, as well as the presence of $\mathrm{V}$ wave, in the contralateral recording.

Another aspect analyzed was the latencyintensity function, in the ipsilateral and contralateral records. A statistically significant difference between genders, in the absolute latencies of $\mathrm{V}$ wave, in intensities of 40 and $30 \mathrm{~dB}$ $\mathrm{nHL}$, in ipsilateral $(\mathrm{p}=0.03$ and $\mathrm{p}=0.000006$, respectively) and contralateral records $(\mathrm{p}=0.08$ and $p=0.01$, respectively), was verified. This way, the normality values, in this study, for the latencyintensity function of $\mathrm{V}$ wave differ according to female and male genders.

Table 4 presents the descriptive statistical analysis and the result for the paired test accomplished to compare the ipsilateral and contralateral records of $\mathrm{V}$ wave's latency, in the various intensities researched, according to genders.

A significant difference was observed in female subjects between the absolute latencies of $\mathrm{V}$ wave, in ipsilateral and contralateral recordings, in intensities of 50 and $30 \mathrm{~dB} \mathrm{nHL}$. 
TABLE 1. Electrophysiological thresholds (dB nHL) obtained by air conduction, bone conduction (vibrator positioned on the mastoid and forehead), absolute latencies of $\mathrm{V}$ wave (ms) obtained by bone conduction with the vibrator positioned on the mastoid, in the various intensities researched (ipsi and contralateral records).

\begin{tabular}{|c|c|c|c|c|c|c|c|c|c|c|c|}
\hline \multicolumn{12}{|c|}{ CASUISTICS DISTRIBUTION - Latency-Intensity Function and Electrophysiological Threshold } \\
\hline \multirow{3}{*}{ Subject/Gender } & \multicolumn{11}{|c|}{ Intensity (dBnHL) } \\
\hline & \multicolumn{5}{|c|}{50} & \multicolumn{2}{|c|}{40} & \multicolumn{2}{|c|}{30} & \multicolumn{2}{|c|}{20} \\
\hline & ACT & BCTM & BCTF & $\begin{array}{l}\text { Ipsi } \\
\text { (ms) }\end{array}$ & $\begin{array}{c}\text { Contra } \\
(\mathrm{ms})\end{array}$ & $\begin{array}{l}\text { Ipsi } \\
\text { (ms) }\end{array}$ & $\begin{array}{c}\text { Contra } \\
\text { (ms) }\end{array}$ & $\begin{array}{l}\text { Ipsi } \\
\text { (ms) }\end{array}$ & $\begin{array}{c}\text { Contra } \\
\text { (ms) }\end{array}$ & $\begin{array}{l}\text { Ipsi } \\
\text { (ms) }\end{array}$ & $\begin{array}{c}\text { Contra } \\
(\mathrm{ms})\end{array}$ \\
\hline 1/Female & 20 & 20 & 30 & 6.60 & 6.63 & 7.03 & 7.03 & 7.63 & 7.77 & 9.33 & 9.33 \\
\hline 2/Male & 20 & 35 & 35 & --- & --- & 6.97 & 6.97 & ---- & ---- & ---- & ---- \\
\hline 3/Female & 15 & 15 & 40 & 6.70 & 6.70 & 7.17 & 7.17 & ---- & 8.30 & 8.30 & ---- \\
\hline 4/Female & 15 & 20 & 20 & 7.0 & 7.0 & 7.33 & 7.47 & 7.93 & 8.07 & --- & ---- \\
\hline 5/ Female & 25 & 25 & 35 & 6.40 & 6.57 & 6.70 & 6.83 & 7.47 & 7.47 & ---- & ---- \\
\hline 6/Male & 15 & 25 & 35 & 7.07 & 7.17 & 7.80 & 7.83 & 8.77 & 8.83 & ---- & ---- \\
\hline 7/ Female & 20 & 30 & - & --- & --- & 7.17 & 7.33 & 8.00 & 8.00 & ---- & ---- \\
\hline 8/ Female & 20 & 20 & 30 & 6.03 & 6.13 & 6.60 & 6.60 & 7.03 & 7.03 & 7.30 & 7.30 \\
\hline 9/Male & 20 & 25 & 40 & 6.33 & 6.33 & 6.97 & 6.97 & 7.73 & 7.73 & ---- & ---- \\
\hline 10/Male & 25 & 30 & 20 & 6.73 & 6.73 & 7.17 & 7.17 & 9.03 & 9.03 & ---- & ---- \\
\hline 11/ Female & 15 & 15 & 30 & 6.60 & 6.70 & 6.90 & 6.90 & 7.50 & 7.73 & 8.10 & 8.10 \\
\hline 12/Male & 20 & 30 & 30 & 7.43 & 7.43 & 7.70 & 7.70 & 8.37 & 8.37 & ---- & ---- \\
\hline 13/Male & 20 & 25 & 35 & 7.27 & 7.27 & 7.80 & 7.80 & 8.73 & 8.73 & ---- & ---- \\
\hline 14/Male & 20 & 40 & 25 & 6.87 & 6.87 & 8.17 & 8.17 & ---- & ---- & ---- & ---- \\
\hline 15/ Female & 20 & 35 & 35 & 7.60 & 7.60 & 7.73 & 7.73 & ---- & ---- & ---- & ---- \\
\hline 16/ Female & 25 & 30 & 35 & 7.10 & --- & 7.93 & 7.1 & ---- & 7.93 & ---- & ---- \\
\hline 17/ Female & 15 & 30 & 40 & 6.43 & 6.50 & 6.70 & 6.87 & 7.23 & 7.23 & ---- & ---- \\
\hline 18/ Female & 20 & 20 & 40 & 6.57 & 6.57 & 6.97 & 7.03 & 7.47 & 7.63 & 8.20 & 8.20 \\
\hline 19/Male & 25 & 30 & 40 & 7.33 & 7.33 & 7.83 & 7.97 & 8.87 & 8.87 & ---- & ---- \\
\hline 20/ Female & 15 & 25 & 30 & 6.33 & 6.40 & 6.83 & 6.83 & 7.30 & 7.40 & ---- & ---- \\
\hline 21/ Female & 15 & 25 & 30 & 6.80 & 6.80 & 7.23 & 7.23 & 7.60 & 7.60 & ---- & ---- \\
\hline 22/ Female & 25 & 40 & 30 & 6.63 & 6.77 & 7.47 & 7.63 & ---- & ---- & ---- & ---- \\
\hline
\end{tabular}

Caption: ACT: air conduction threshold; BCTM: bone conduction threshold (mastoid); BCTF: bone conduction threshold (Forehead)

TABLE 2. Electrophysiological threshold with the bone vibrator positioned on the forehead and mastoid, in the subjects evaluated. Result of Student's $t$ test while comparing the genders in the different positions of the vibrator.

\begin{tabular}{cccccc}
\hline \multicolumn{2}{c}{ ELECTROPHYSIOLOGICAL THRESHOLD BY BONE CONDUCTION (dBnHL) } \\
\hline \multicolumn{2}{c}{ Mastoid } & \multicolumn{3}{c}{ Forehead } \\
\hline & Female & Male & Female & Male \\
\hline Mean & 25.00 & 30.00 & 32.69 & 32.50 \\
SD & 7.33 & 5.34 & 5.63 & 7.07 & 20.00 \\
Minimum & 15.00 & 25.00 & 20.00 & 40.00 \\
Maximum & 40.00 & & 40.00 & 40.00 & 0.945 \\
\hline
\end{tabular}

TABLE 3. Descriptive statistical analysis and the result of the paired $t$ test accomplished to compare the electrophysiological thresholds (dB nHL) obtained through air and bone conduction, for females, males and with all subjects grouped.

\begin{tabular}{|c|c|c|c|c|c|c|}
\hline \multicolumn{7}{|c|}{ ELECTROPHYSIOLOGICAL THRESHOLDS - dBnHL } \\
\hline & \multicolumn{2}{|c|}{ Female } & \multicolumn{2}{|c|}{ Male } & \multicolumn{2}{|c|}{ Both s } \\
\hline & $\begin{array}{c}\text { Air } \\
\text { Conduction }\end{array}$ & $\begin{array}{c}\text { Bone } \\
\text { Conduction }\end{array}$ & Air Conduction & $\begin{array}{c}\text { Bone } \\
\text { Conduction }\end{array}$ & Air Conduction & $\begin{array}{c}\text { Bone } \\
\text { Conduction }\end{array}$ \\
\hline Mean & 18.93 & 25.00 & 20.62 & 30.00 & 19.54 & 26.81 \\
\hline SD & 4.01 & 7.34 & 3.20 & 5.34 & 3.75 & 6.99 \\
\hline Minimum & 15.00 & 15.00 & 15.00 & 25.00 & 15.00 & 15.00 \\
\hline Maximum & 25.00 & 40.00 & 25.00 & 40.00 & 25.00 & 40.00 \\
\hline $\mathrm{P}$ & \multicolumn{2}{|c|}{$0.003^{*}$} & \multicolumn{2}{|c|}{$0.002 *$} & \multicolumn{2}{|c|}{$0.00001^{*}$} \\
\hline
\end{tabular}

${ }^{*} \mathrm{p} \leq 0.05$ : statistically significant 
TABLE 4. Descriptive statistical analysis of $\mathrm{V}$ wave's latency in the various intensities researched, according to genders and paired $t$ test for the comparison of ipsilateral (ipsi) and contralateral (contra) records.

\section{LATENCY-INTENSITY FUNCTION OF V WAVE (ms)}

Intensity

(dBnHL)

Bone Conduction

\begin{tabular}{|c|c|c|c|c|c|c|c|c|c|c|c|}
\hline & & Mean & SD & Minimum & Maximum & $\mathrm{p}$ & Mean & SD & Minimum & Maximum & $\mathrm{p}$ \\
\hline \multirow{2}{*}{50} & Ipsi & 6.64 & 0.39 & 6.03 & 7.60 & \multirow{2}{*}{$0.008^{*}$} & 7.00 & 0.39 & 6.33 & 7.43 & \multirow{2}{*}{0.355} \\
\hline & Contra & 6.70 & 0.36 & 6.13 & 7.60 & & 7.02 & 0.39 & 6.33 & 7.43 & \\
\hline \multirow{2}{*}{40} & Ipsi & 7.13 & 0.39 & 6.60 & 7.93 & \multirow{2}{*}{0.991} & 7.55 & 0.45 & 6.97 & 8.17 & \multirow{2}{*}{0.260} \\
\hline & Contra & 7.12 & 0.33 & 6.60 & 7.73 & & 7.57 & 0.47 & 6.97 & 8.17 & \\
\hline \multirow{2}{*}{30} & Ipsi & 7.52 & 0.30 & 7.03 & 8.00 & \multirow[t]{2}{*}{$0.020^{*}$} & 8.58 & 0.47 & 7.73 & 9.03 & \multirow[t]{2}{*}{0.362} \\
\hline & Contra & 7.59 & 0.32 & 7.03 & 8.30 & & 8.59 & 0.48 & 7.73 & 9.03 & \\
\hline \multirow{2}{*}{20} & Ipsi & 8.23 & 0.83 & 7.30 & 9.33 & \multirow{2}{*}{---- } & ---- & ---- & ---- & ---- & \multirow{2}{*}{---- } \\
\hline & Contra & 8.23 & 0.83 & 7.30 & 9.33 & & ---- & --- & --- & ---- & \\
\hline
\end{tabular}

${ }^{*} \mathrm{p} \leq 0.05$ : statistically significant

FIGURE 1. Electrophysiological threshold, ipsilateral recording, obtained in a female subject, with the vibrator positioned on the forehead.

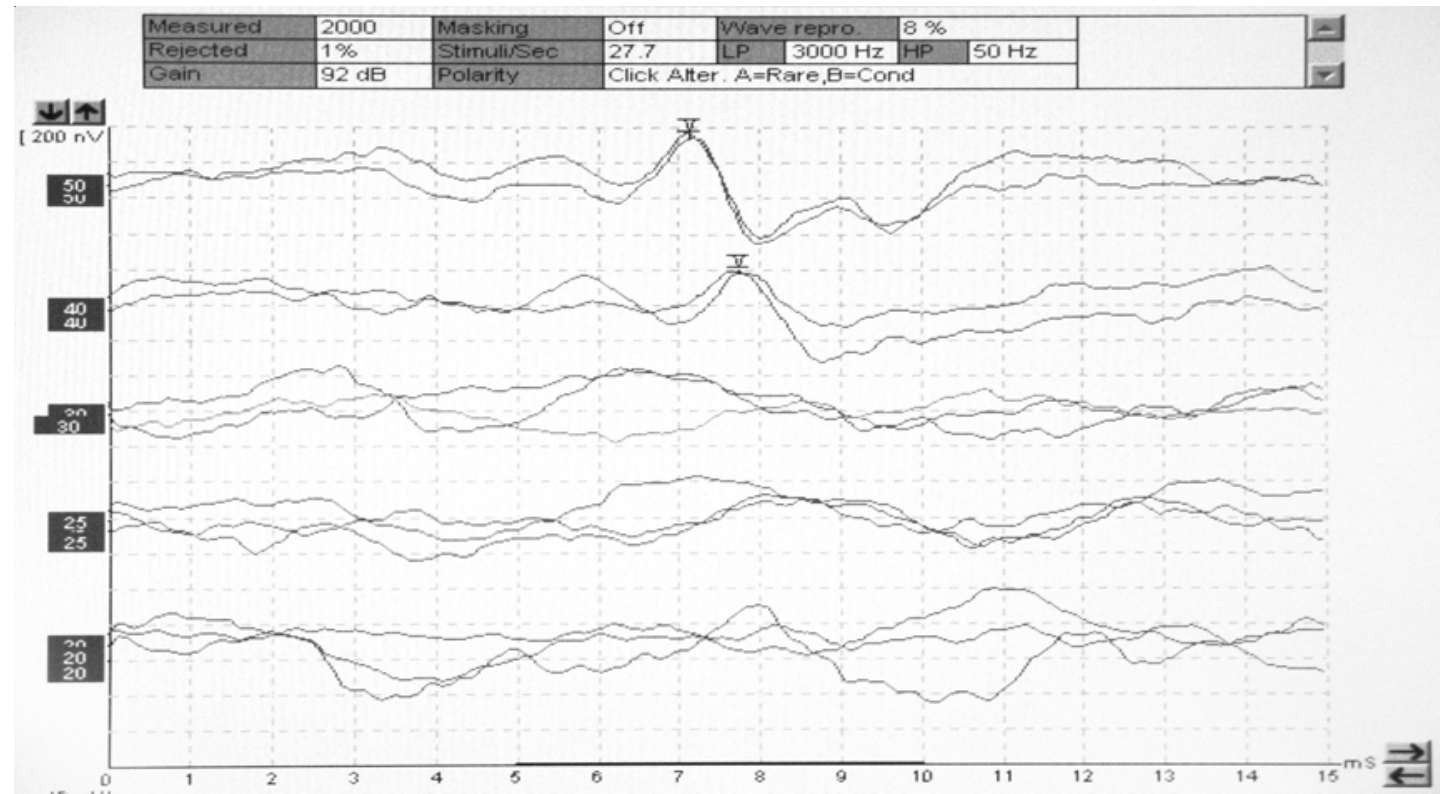


FIGURE 2. Electrophysiological threshold, ipsilateral recording, obtained in a female subject, with the vibrator positioned on the mastoid.

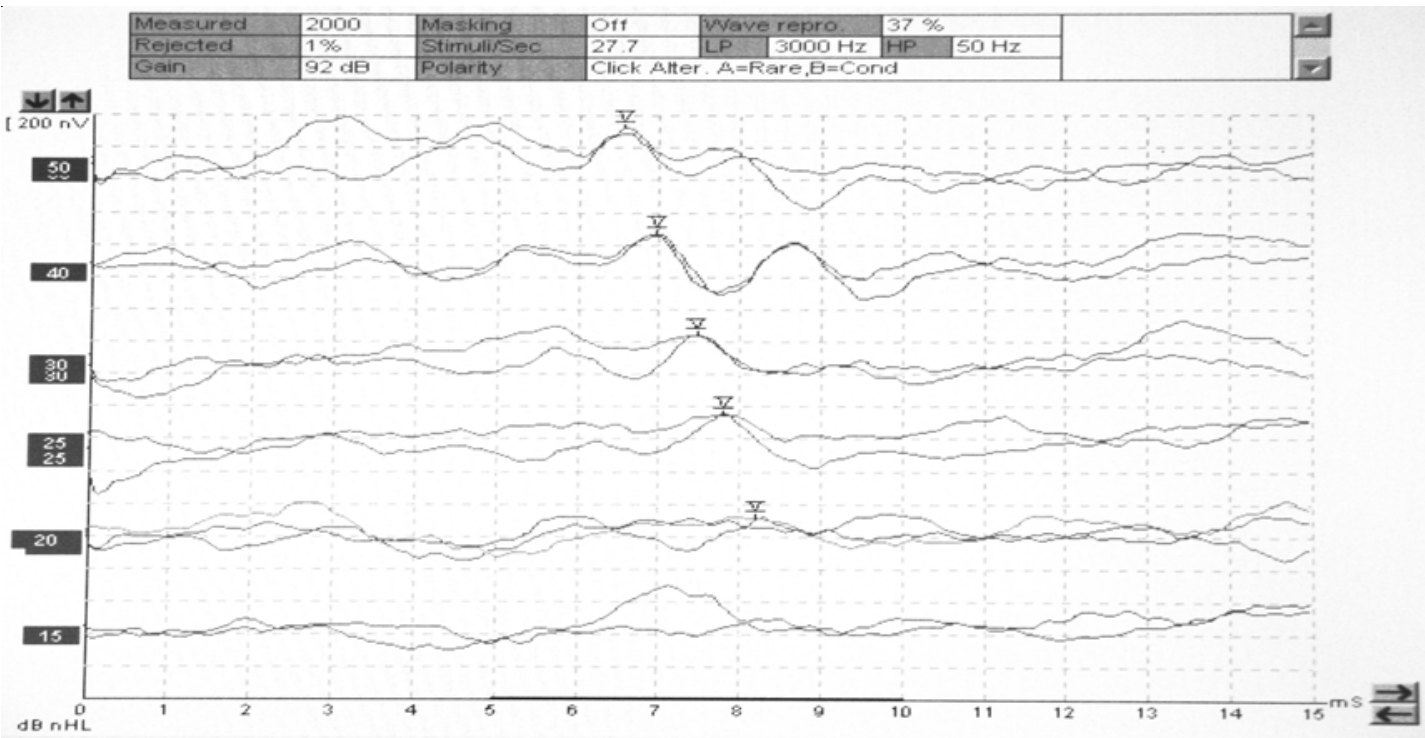

\section{Discussion}

In the present study, the electrophysiological threshold by bone conduction to analyze the most suitable positioning of the vibrator (mastoid or forehead) was utilized, as opposed to the work by Yang et al. (1987), who studied the absolute latency of $\mathrm{V}$ wave.

Out of the total evaluated, only one subject did not present recordings of ABR when the vibrator was positioned on the forehead, as shown in Table 1. The results demonstrated that the electrophysiological threshold obtained with the vibrator on the forehead $(32,69 \pm 5,63$ and $32,5 \pm 7,07$ $\mathrm{dBnHL}$ ) was greater than when the vibrator was placed on the mastoid $(25 \pm 7,33$ and $30 \pm 5,34$ $\mathrm{dBnHL}$ ), both for female and male genders, respectively (Tables 1 and 2 and Figures 1 and 2), which is consistent with the description by Shiraishi et al. (1985) apud Kaga and Tanaka (1995). Therefore, the option of placing the vibrator on the forehead was not assumed, since, besides most individuals reported an intense discomfort with the vibrator in this position, the necessary correction factor would be greater, and consequently, one more variable to be analyzed in the research of ABR by bone conduction. Probably, this finding presents acoustics and physiological justifications. First, the calibration of the vibrator is accomplished on the artificial mastoid, i.e, the intensity relative to the $0 \mathrm{dBnHL}$ for each frequency is defined considering this particular structure. Second, the bone structure of the forehead is more compact, offering a greater impedance to sound transmission, being necessary more energy for skull vibration to take place, thus justifying the high electrophysiological threshold. This way, it is recommended that the research of electrophysiological threshold, by bone conduction ABR be accomplished with the vibrator positioned on the mastoid, as described by Shiraishi et al. (1985) apud Kaga and Tanaka (1995).

In this study, the electrophysiological threshold obtained by bone conduction presented a value of $25 \pm 7.33 \mathrm{dBnHL}$ with a minimum value of $15 \mathrm{dBnHL}$ for females and $30 \pm 5.34 \mathrm{dBnHL}$ with a minimum value of $25 \mathrm{dBnHL}$ for males (Table 2). Although the electrophysiological threshold by bone conduction in male subjects is more elevated, there was no statistically significant difference when the genders were compared ( $\mathrm{p}=0.108)$.

Thus, the data of all grouped subjects were utilized to analyze the normality of electrophysiological threshold by bone conduction. Therefore, the value of $26.81 \pm 6.99$ $\mathrm{dBnHL}$ was adopted as the normality reference. 
Another important aspect is that the electrophysiological threshold by bone conduction (26.81 \pm 6.99$)$ was greater that the threshold by air conduction (19.54 $\pm 3.75 \mathrm{dBnHL})$, with a statistically significant difference, being necessary to utilize the correction factor, which according to the results must be approximately $10 \mathrm{dBnHL}$, i.e., $10 \mathrm{dBnHL}$ by bone conduction corresponds to approximately $0 \mathrm{dBnHL}$ by air conduction (Table 3 ). The findings are consistent with those described by Cornacchia et al, (1983) e Stuart and Yang, (2001).

Table 4 shows that, in female subjects, a significant difference was seen between the absolute latencies of $\mathrm{V}$ wave in ipsilateral and contralateral records, in intensities of 50 and $30 \mathrm{dBnHL}$. Although the mean values of $\mathrm{V}$ wave latencies for ipsi and contralateral records were quite close in these intensities, it was observed that, whenever there was a difference in latency, it was greater in the contralateral record. This is a relevant fact because it shows a tendency for the latency to be always greater in a direction, in that case, in the contralateral record.

Thus, according to the results obtained, the protocol proposed for the research of electrophysiological threshold by bone conduction is:

- the vibrator positioned on the mastoid of the ear in which the electrophysiological threshold will be researched;

- ipsilateral record to the ear stimulated (utilization of a recording channel, being the active electrode in $\mathrm{Fz}$ and reference in $\mathrm{A} 1$ or $\mathrm{A} 2$, ipsilateral to the ear stimulated;

- value of normality in the casuistic to be utilized for the latency of $\mathrm{V}$ wave $(\mathrm{ms})$ in females: $6.64 \pm 0.39$ in the intensity of $50 \mathrm{dBnHL} ; 7.13 \pm 0.39$ in the intensity of $40 \mathrm{dBnHL} ; 7.52 \pm 0.30$ in the intensity of $30 \mathrm{dBnHL}$ and $8.23 \pm 0.83$ in the intensity of 20 dBnHL. In males: $7.00 \pm 0.39$ in the intensity of 50 $\mathrm{dBnHL} ; 7.55 \pm 0.45$ in the intensity of $40 \mathrm{dBnHL}$ and $8.58 \pm 0.47$ in the intensity of $30 \mathrm{dBnHL}$. The $\mathrm{V}$ wave, in the intensity of $20 \mathrm{dBnHL}$ was not registered in all male subjects assessed.

In the case that the electrical artifact level is very intense, interfering in the recording, for example, in some individuals presented with external ear malformation, in which the vibrator and electrode are very close (vibrator positioned on the mastoid), the following protocol may be utilized:
- the vibrator is positioned on the mastoid of the ear in which the electrophysiological threshold is to be researched;

- contralateral record to the ear stimulated (utilization of one recording channel, being the electrode active in $\mathrm{Fz}$ and reference in $\mathrm{M} 1$ or M2, contralateral to the ear stimulated);

- the normality standard to be utilized for the latency of V wave (ms) in the contralateral record is: for females, $6.70 \pm 0.36$ in the intensity of $50 \mathrm{dBnHL}$; $7.12 \pm 0.33$ in the intensity of $40 \mathrm{dBnHL} ; 7.59 \pm 0.32$ in the intensity of $30 \mathrm{dBnHL}$ and $8.23 \pm 0.83$ in the intensity of $20 \mathrm{dBnHL}$. For males, the values will be: $7.02 \pm 0.39$ in the intensity of $50 \mathrm{dBnHL} ; 7, .570 .47$ in the intensity of $40 \mathrm{dBnHL}$ and 8.590 .48 in the intensity of $30 \mathrm{dBnHL}$. The $\mathrm{V}$ wave, in the intensity of $20 \mathrm{dBnHL}$ was not registered in all male subjects assessed.

Thus, there will be a reduction of the electrical artifact, owing to the distance between the electrode and the vibrator. However, it is important to highlight that, the recording of wave I is lost in the contralateral record, which in some cases of asymmetric or unilateral hearing loss helps to define the use of masking in the contralateral ear.

Another important aspect is that, the value for reference of normality must be analyzed, taking into account the potentials' recording system which is being utilized, that is, the biological calibration must be always carried out for the definition of correct diagnoses (Flabiano et al. 2002).

The research of ABR by bone conduction is more complex than by air conduction, requiring extra care and technical competence of the examiner, as for decision making to reduce the electrical artifact, generally present (Campbell et al. 2004), and mainly for the accurate analysis of the recording which presents morphology, in some cases, with a reproducibility of difficult visualization.

The possibility of researching the functionality of the inner ear in individuals presented with malformation, by bone conduction ABRs, is clinically extremely important, since, as described by Silveira et al. (2003), the characterization and classification of the hearing loss in these subjects will allow the treatment to be defined according to the clinical picture presented and begun as early as possible. 


\section{Conclusion}

Based on the findings of this work, it was concluded that the bone conduction auditory brainstem responses can be carried out in the clinical practice and along with air conduction potentials, increase the possibilities of a more precise diagnosis as for the type of hearing loss.

\section{Referências Bibliográficas}

CAMPBELL, P.; HARRIS, C.; HENDRICKS, S.; SIRIMANNA, T. Bone conduction auditory brainstem responses in infants. J. Laryngol Otol., London, v. 118, n. 2, p. $117-122$, feb. 2004

CHAPCHAP, M. Respostas elétricas de tronco encefálico por estimulação aérea e óssea em neonatos. 2002. $80 \mathrm{f}$. Dissertação (Mestrado em Distúrbios da Comunicação Humana) - Curso de Fonoaudiologia, Universidade Federal de São Paulo, São Paulo.

CORNACCHIA, L.; MARTINI, A.; MORRA, B. Air and bone conduction brain stem responses in adults and infants. Audiol., New York, v. 22, n. 5, p. 430-437, sep.-oct. 1983.

DOYLE, K.; KONG, Y.; STROBEL, K.; DALLAIRE, P.; RAV, R. M. Neonatal middle ear effusion predicts chronic otitis media with effusion. Otol Neurotol., Hagerstown, v. 25, n. 3, p. 318-322, may. 2004.

FICHINO, S. Estudo do potencial evocado auditivo de tronco encefálico por via aérea e via óssea em crianças de até dois meses de idade. 2005. 83 f. Dissertação (Mestrado em Fonoaudiologia) - Faculdade de Fonoaudiologia, Pontifícia Universidade Católica de São Paulo, São Paulo.

FLABIANO, F.; LEITE, R.; MATAS, C. Audiometria de tronco encefálico em adultos audiologicamente normais: comparação das latências absolutas das ondas I, III, V, interpicos I-III, III-V, I-V, amplitudes das ondas I, III, V e relação da amplitude V/I, obtidas em dois equipamentos diferentes. Acta AWHO, São Paulo, v. 21, n. 2, abr.-jun. 2002. Disponível em: <http://www.actaawho.com.br/ edicao/conteudo.asp?edi_id=58tpc_id=18con_id=11.>. Acesso em: 20 ago. 2006.

FREITAS, V.; MORETTIN, M.; AGOSTINHO, R.; SOUZA, E.; ALVARENGA, K.; COSTA, O. Potenciais evocados auditivos de tronco encefálico por via óssea no diagnóstico audiológico de crianças com malformação de orelha externa e/ou média. In: ENCONTRO INTERNACIONAL DE AUDIOLOGIA, 19., 2004, Bauru. Anais... Bauru: Academia Brasileira de Audiologia, 2004. CD-ROM.

FUZETTI, C.; LEWIS, D. Emissões otoacústicas espontâneas e evocadas por estímulo transiente em recémnascidos. Pró-Fono R. Atual. Cient., Barueri, v. 15, n. 2, p. 189-198, maio-ago. 2003.

GORGA, M.; KAMINSKI, J.; BEAUCHAINE, K.; BERGMAN, B. A comparison of auditory brain stem response thresholds and latencies elicited by air-and boneconducted stimuli. Ear Hear., Baltimore, v. 14, n. 2, p. 85-94, apr. 1993.
HOF, J.; ANTEUNIS, L.; CHENAULT, M.; VAN DIJK, P. Otoacoustic emissions at compensated middle ear pressure in children. Int. J. Audiol., Hamilton, v. 44, n. 6, p. 317320, jun. 2005.

JANSSEN, I.; GEHR, D.; KLEIN, A.; MULLER, J. Distortion product otoacoustic emissions for hearing threshold estimation and differentiation between middleear and cochlear disorders in neonates. J. Acoust. Soc. Am., Lancaster, v. 117, n. 5, p. 2969-2979, may. 2005.

LUTS, H.; DESLOOVERE, C.; DUMAR, A.; VANDERMEERSCH, E.; WOUTERS, J. Objective assessment of frequency-specific hearing thresholds in babies. Int. J. Pediatr. Otorhinolaryngol., Amsterdam, v. 68, n. 7, p. 915-926, jul. 2004.

MAULDIN, L.; JERGER, J. Auditory brain stem evoked responses to bone-conducted signals. Arch. Otolaryngol., Chicago, v. 105, n. 11, p. 656-661, nov. 1979.

OOSTENBRINK, P.; VERHAAGEN-WARNAAR, N. Otoacoustic emissions. Am. J. Electroneurodiagnostic. Technol., Carroll, v. 44, n. 3, p. 189-198, sep. 2004.

ROBERSON JR., J. B.; O'ROURKE, C.; STIDHAM, K. R. Auditory steady-state response testing in children: evaluation of a new technology. Otolaryngol. Head Neck Surg., Rochester, v. 129, n. 1, p. 107-113, jul. 2003.

SANTIAGO-RODRIGUEZ, E. et al. Auditory steady-state responses in infantes with perinatal brain injury. Pediatr. Neurol., New York, v. 32, n. 4, p. 236-240, apr. 2005.

SHIRAISHI, K.; SDA, T.; KATO, J. Bone ABRs at different stimulus sites. Audiol., Japão, n. 28, p. 451-452, 1985. Apud: KAGA, K.; TANAKA, Y. Auditory air and bone conduction brainstem responses and damped rotation test for young children with bilateral congenital atresia of the ears. Int. J. Pediatr. Otorhinolaryngol., Amsterdam, v. 32, n. 1, p. 13-21, apr. 1995.

SHEYKHOLESLAMI, K.; MOHAMMAD, H. K.; SÉBASTEIN, S.; KAGA, K. Binaural interaction of boneconducted auditory brainstem responses in children with congenital atresia of the external auditory canal. Int. J. Pediatr. Otorhinolaryngol., Amsterdam, v. 67, n. 10, p. 1083-1090, oct. 2003.

SILVEIRA, T. da.; CASTIQUINI, E.; SHAYEB, D.; MEYER, A. Adaptação de AASI em paciente portador de agenesia de conduto auditivo externo. Pró-Fono R. Atual. Cient., Barueri, v. 15, n. 1, p. 95-100, jan.-abr. 2003.

SOHMER, H.; FREMAN, S. The latency of auditory nerve brainstem evoked responses to air-and bone-conducted stimuli. 
Hear. Res., Amsterdam, v. 160, n. 1-2, p. 111-113, oct. 2001.

SOHMER, H.; FREEMAN, S.; GEAL DOR, M.; ADELMAN, C.; SAVION, I. Bone conduction experiments in humans: a fluid pathway from bone to ear. Hear. Res., Amsterdam, v. 146, n. 1 e n. 2, p. 81-88, mês. 2000.

STUART, A.; YANG, E. Gender effects in auditory brainstem responses to air- and bone- conducted clicks in neonates. Communic. Disord., Amsterdam, v. 34, n. 3, p. 229-239, may-jun. 2001.

STUEVE, M.; O'ROURKE, C. Estimation of hearing loss in children: comparison of auditory steady-state response, auditory brainstem response, and behavioral test methods. Am. J. Audiol., Rockville, v. 12, n. 2, p. 125-136, dec. 2003.

SWANEPOEL, D.; HUGO, R.; ROODE, R. Auditory Steady-State response for children with severe to profound hearing loss. Arch Otolaryngol. Head Neck Surg., Chicago, v. 130, n. 5, p. 531-535, may. 2004.

YANG, E.; RUPERT, A.; MOUSHEGIAN, G. A developmental study of bone conduction auditory brain stem response in infants. Ear Hear., Baltimore, v. 8, n. 4, p. 244-251, aug. 1987. 